DOI:

\title{
Thick section reformatted computed tomography images are useful for the diagnosis of hepatopulmonary syndrome: A case report
}

\author{
Hepatopulmoner sendrom tanısında kalın kesit reformatlı bilgisayarlı tomografi görüntülerinin \\ değeri: Bir olgu sunumu
}

Atilla Hikmet ÇILLENGİR, Şebnem KARASU, Yusuf Kenan ÇETINNOĞLU, Muhsin Engin ULUÇ, Özgür TOSUN

\begin{abstract}
Respiratory complications, which range from mild hypoxemia to hepatopulmonary syndrome, can occur due to some mediators within the circulation in end-stage liver disease. Intrapulmonary vascular dilatations and shunts are the reasons of these complications. Thoracic imaging modalities such as radiography and computed tomography (CT) can be performed to evaluate these vascular pathologies. We reported a 37-year-old woman with previously known liver cirrhosis, presented with new onset exertional dyspnea. There were intrapulmonary shunts and dilated vascular structures on her thorax CT. She was diagnosed with hepatopulmonary syndrome by clinical symptoms, laboratory and imaging findings. Thick section reformatted images of CT are superior in demonstration of intrapulmonary shunts and dilated vascular structures compared with thin section axial source images; so we recommend that thorax CT of cirrhotic patients must be evaluated with thick section reformatted images for the determination of intrapulmonary shunts and dilated vascular structures.
\end{abstract}

Keywords: Computed tomography, Hepatopulmonary syndrome, Liver cirrhosis
Öz

Son dönem karaciğer hastalığında dolaşımdaki bazı mediatörlere bağlı olarak hafif hipoksemiden hepatopulmoner sendroma kadar uzanan spektrumda solunum komplikasyonları görülebilmektedir. İntrapulmoner vasküler dilatasyonlar ve şantlar bu komplikasyonlardan sorumludur. Radyografi ve bilgisayarlı tomografi (BT) gibi toraks görüntüleme modaliteleri bu vasküler patolojilerin değerlendirilmesinde kullanılabilir. $\mathrm{Bu}$ olgu sunumunda bilinen karaciğer sirozu olan ve yeni başlayan egzersiz dispnesi ile başvuran 37 yaşında kadın hastanın direkt grafi ve BT bulgularından bahsettik. Hastanın toraks BT'sinde intrapulmoner şantlar ve dilate vasküler yapılar mevcuttu. Hastamız, klinik, laboratuvar ve radyolojik bulguları sonucunda hepatopulmoner sendrom tanısını aldı. Kalın kesit reformatlı BT görüntüleri intrapulmoner şantlar ve dilate vasküler yapıları kaynak görüntü olarak kullanılan ince kesit BT'den daha iyi bir şekilde göstermiştir. $\mathrm{Bu}$ nedenle siroz hastalarında, intrapulmoner şantlar ve vasküler dilatasyonların belirlenmesinde toraks BT'lerinin reformatlı kalın kesitlerle de değerlendirilmesini önermekteyiz.

Anahtar kelimeler: Bilgisayarlı tomografi, Hepatopulmoner sendrom, Karaciğer sirozu

\section{Introduction}

Chronic liver disease is characterized by progressive destruction and regeneration of the liver parenchyma and eventually results in liver failure. In the end-stage disease, many systems can be affected and also respiratory complications can be seen. Mild hypoxemia is a frequent feature of cirrhosis but dyspnea and hepatopulmonary syndrome are seen in only $15-20 \%$ of the patients with cirrhosis [1]. In hepatopulmonary syndrome; peripheral tissue oxygenation is impaired due to intrapulmonary vascular dilatations and shunts. These vascular pathologies increase the alveolar-arterial oxygen gradient. Due to liver dysfunction, the amounts of vasodilator factors such as nitric oxide increase in circulatory system while 
their clearance is decreased. This is accepted as the main cause of intrapulmonary shunts and vasodilatation [2]. In this case report, we presented the imaging findings of hepatopulmonary syndrome in a cirrhotic patient.

\section{Case Report}

A 37-year-old woman with previously known liver cirrhosis, presented with new onset exertional dyspnea. She had a history of chronic liver disease due to hepatitis B, portal hypertension and splenectomy. On physical examination, she had cyanosis but the auscultation findings were normal. Partial oxygen pressure was $69 \mathrm{mmHg}$ and oxygen saturation was $92 \%$ in arterial blood gas test. The systolic pulmonary artery pressure was measured as $25 \mathrm{mmHg}$ by echocardiography. Peripherally located nodular and reticulonodular opacities were seen on her chest radiograph. Also, a tubular opacity, which could be related to a dilated vascular structure, was located on the left lung basal area. On her thorax computed tomography (CT), there were dilatations in peripheral vascular structures and connections between peripheral pulmonary arteries and veins compatible with intrapulmonary arteriovenous shunts which were better demonstrated with thick section reformatted maximum intensity projection (MIP) images of CT (Figure 1a and b). Contrast echocardiography was performed by using intravenous agitated saline to establish the diagnosis. Agitated saline, located in the right atrium, was seen in the left atrium after 5 heartbeats. This finding showed the

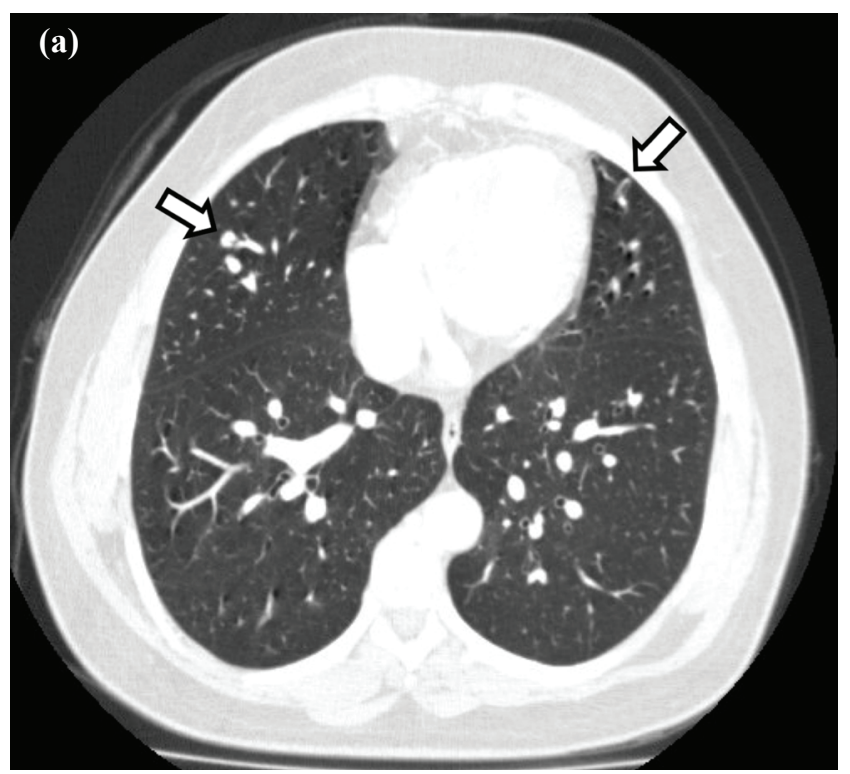

presence of intrapulmonary shunts. Supplemental oxygen treatment was started to improve respiratory functions and she was followed up for 18 months. In this interval, her exertional dyspnea decreased and chest radiograph findings were stable.

\section{Discussion}

Hepatopulmonary syndrome is the clinical situation which includes liver function abnormalities, intrapulmonary vascular dilatations and hypoxemia [2]. The prevalence of hepatopulmonary syndrome in adult cirrhotic patients ranges between $15-20 \%$ [1]. Krowka et al., found that dyspnea is the presenting symptom in $18 \%$ of the patients [3]. Cyanosis and clubbing are the prominent findings of severe hypoxemia [4]. Ventilation-perfusion mismatch because of the pulmonary arteriovenous shunts and oxygen diffusion limitations are responsible for hepatopulmonary syndrome [5]. The characteristic chest radiograph findings of hepatopulmonary syndrome are nodular-reticulonodular opacities which locate middle-basal zones of the lungs. Cardiomegaly and enlargement of central pulmonary vessels also can be seen [6]. There are two types of CT angiography findings. The most common type (type 1), which includes $86 \%$ of the patients, is characterized by subpleural telangiectasia and peripheral vascular dilatation. Type 2 hepatopulmonary syndrome ( $14 \%$ of patients) is characterized by arteriovenous malformations and nodular dilatations in peripheral pulmonary arteries $[1,3,7]$.

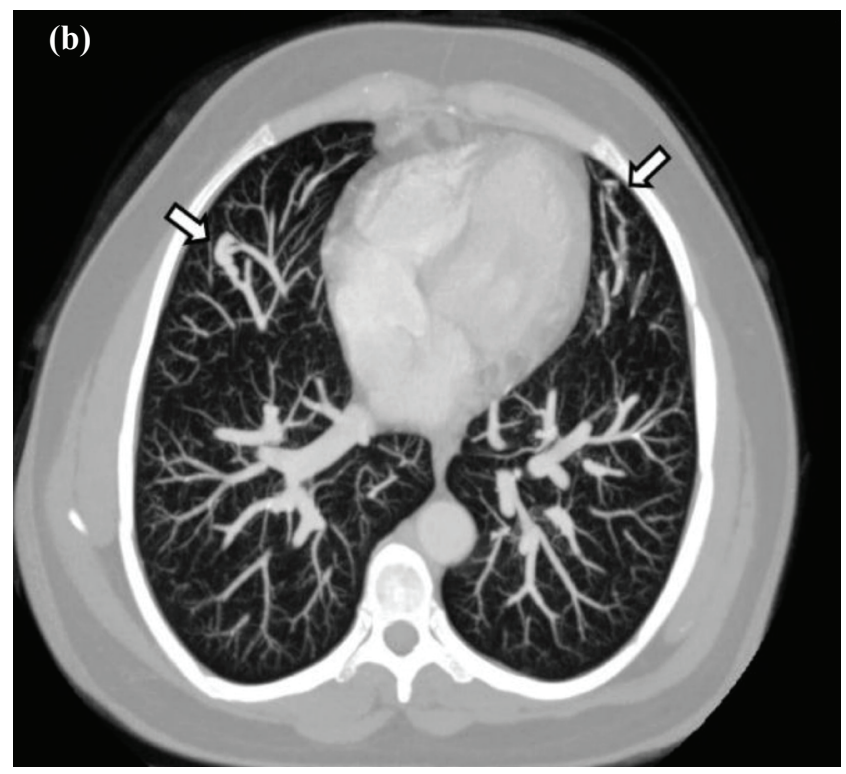

Figure 1. Dilated vascular structures (arrow) are seen on thin section axial CT image (1 mm) (a). Dilated vascular structures and shunts are better evaluated on thick section ( $8 \mathrm{~mm}$ ) axial reformatted MIP image of CT (b). 
Peripheral vascular dilatations were evident in our case. Lee et al., found a statistically significant difference between the mean diameters of segmental bronchial arteries on CT in patients with hepatopulmonary syndrome $(7.6 \mathrm{~mm})$ and in normoxemic cirrhotic patients $(4.7 \mathrm{~mm})$ [8]. In our case, the diameters of segmental bronchial arteries range from $5.4 \mathrm{~mm}$ to $7.5 \mathrm{~mm}$. It could be difficult to distinguish the vascular shunts on thin section CT images. In that case, MIP reformatting on $\mathrm{CT}$ images with thick section can be a choice to concretize the vascular structures. We used $8 \mathrm{~mm}$ slab thickness while MIP reformatting of thin section $(1 \mathrm{~mm})$ axial CT images in this case. Contrast echocardiography is the most useful diagnostic technique to prove the existence of intrapulmonary shunts $[2,8,9]$. There is no curative medical treatment of hepatopulmonary syndrome yet. Liver transplantation is thought to be the most successful treatment of choice [10].

\section{Conclusion}

Chest radiograph and $\mathrm{CT}$ are the radiological diagnostic techniques for evaluation of the hepatopulmonary syndrome. Subpleural telangiectasia, arteriovenous shunts and nodular dilatations in peripheral pulmonary arteries can be seen in patients with hepatopulmonary syndrome on CT. Thick section reformatted MIP images are better than thin section CT images for demonstration of the vascular abnormalities in these patients. We recommend that chest CT of patients with cirrhosis must be evaluated with thick section reformatted MIP images for the determination of intrapulmonary shunts and dilated vascular structures. If these findings are seen, hepatopulmonary syndrome should be thought and patient should be evaluated with contrast echocardiography to establish the diagnosis.

\section{References}

1. Kim YK, Kim Y, Shim SS. Thoracic complications of liver cirrhosis: radiologic findings. Radiographics 2009;29:82537. doi: $10.1148 /$ rg. 293085093

2. Fallon MB, Abrams GA. Hepatopulmonary syndrome. Curr Gastroenterol Rep 2000;2:40-5.

3. Krowka MJ, Dickson ER, Cortese DA. Hepatopulmonary syndrome: clinical observations and lack of therapeutic response to somatostatin analogue. Chest 1993;104:515-21.

4. Leung AN. Case 63: hepatopulmonary syndrome. Radiology 2003;229:64-7.

5. Krowka MJ, Porayko MK, Plevak DJ, et al. Hepatopulmonary syndrome with progressive hypoxemia as an indication for liver transplantation: case reports and literature review. Mayo Clin Proc 1997;72:44-53. doi: 10.1016/S00256196(11)64729-0

6. Scott VL, Dodson SF, Kang Y. The hepatopulmonary syndrome. Surg Clin North Am 1999;79:23-41, vii.

7. McAdams HP, Erasmus J, Crockett R, Mitchell J, Godwin JD, McDermott VG. The hepatopulmonary syndrome: radiologic findings in 10 patients. AJR Am J Roentgenol 1996;166:1379-85. doi: 10.2214/ajr.166.6.8633451

8. Lee KN, Lee HJ, Shin WW, Webb WR. Hypoxemia and liver cirrhosis (hepatopulmonary syndrome) in eight patients: comparison of the central and peripheral pulmonary vasculature. Radiology 1999;211:549-53. doi: 10.1148/ radiology.211.2.r99ma46549

9. Abrams GA, Jaffe CC, Hoffer PB, Binder HJ, Fallon MB. Diagnostic utility of contrast echocardiography and lung perfusion scan in patients with hepatopulmonary syndrome. Gastroenterology 1995;109:1283-8.

10. Colle I, Van Steenkiste C, Geerts A, Van Vlierberghe H. Hepatopulmonary syndrome and portopulmonary hypertension: what's new?. Acta Gastroenterol Belg 2007;70:203-9. 